\title{
PROFIL SOCIAL SELF OF WELLNESS MAHASISWA STRATA 1 FAKULTAS ILMU PENDIDIKAN UNIVERSITAS NEGERI JAKARTA
}

\author{
Nursamsiah ${ }^{1}$ \\ Dra. Endang Setiyowati ${ }^{2}$ \\ Karsih, M.Pd ${ }^{3}$
}

\begin{abstract}
Abstrak
Penelitian ini bertujuan untuk mengetahui profil social self of wellness mahasiswa Strata 1 Fakultas Ilmu Pendidikan Universitas Negeri Jakarta. Metode yang digunakan adalah deskriptif dengan jenis penelitian survei. Populasi dalam penelitian ini adalah seluruh mahasiswa Fakultas Ilmu Pendidikan Universitas Negeri Jakarta angkatan 2014, 2013, 2012, dan 2011 yang berjumlah 3.291 mahasiswa, dengan jumlah sampel sebanyak 317 responden, menggunakan teknik proportionate stratified random sampling. Pengumpulan data dilakukan dengan menggunakan instrumen social self yang dikembangkan dari dimensi model the indivisible self dalam teori wellness yang dikemukakan oleh Myers dan Sweeney. Analisis data hasil penelitian menggunakan teknik statistik deskriptif. Hasil penelitian menunjukkan bahwa 53,9\% (171 mahasiswa) berada pada kategori tinggi, 46,1\% (146 mahasiswa) berada pada kategori sedang dan tidak ada mahasiswa pada kategori rendah. Kesmipulan dari penelitian ini adalah sebagian besar mahasiswa berada pada ketegori tinggi yang artinya mahasiswa Fakultas Ilmu Pendidikan Universitas Negeri Jakarta memiliki kemampuan social self yang baik.
\end{abstract}

Kata Kunci : Wellness, Social Self, Mahasiswa

\section{Pendahuluan}

Wellness adalah sebuah konsep "sejahtera" yang multidimensional. Konsep ini diambil dari perspektif kepribadian, sosial, klinis, kesehatan, psikologi perkembangan, antropologi, agama dan pendidikan. Multidimensional artinya kondisi sehat itu terjadi dalam berbagai dimensi kehidupan yang mencakup dimensi fisik, emosional, sosial, spiritual dan intelektual.

Menurut Myers dan Sweeney (2005: 33) kondisi wellness individu dapat dilihat dari lima dimensi, yaitu creative self, coping self, social self, essential self, dan physical self. Model ini disebut juga The Indivisible Self of Wellness (IS-Wel). Jika individu mampu menyeimbangkan kelima dimensi tersebut, maka ia memiliki wellness yang baik.

Salah satu yang termasuk dalam komponen wellness yaitu mengenai social self. Menurut Myers dan Sweeney (2008: 485) social self merupakan dukungan sosial melalui hubungan dengan orang lain dalam persahabatan dan hubungan personal yang lebih intens (intim), termasuk ikatan keluarga.Kom-

\footnotetext{
1 Mahasiswa Jurusan Bimbingan dan Konseling FIP UNJ, nursamsiah2010@gmail.com

2 Dosen Bimbingan dan Konseling FIP UNJ, esetiyowati63@yahoo.com

3 Dosen Bimbingan dan Konseling FIP UNJ, karsih5979@gmail.com
} 
ponen ini terdiri dari cinta dan persahabatan. Berdasarkan definisi social self tersebut, tersirat bahwa dukungan sosial berkaitan erat dengan hubungan interpersonal seperti hubungan persahabatan, hubungan akrab dan hubungan keluarga.

Menurut Myers dan Sweeney (2005: 27) dukungan sosial yang dirasakan oleh individu berkolerasi positif dengan kesehatan fisik dan emosional serta mampu mengurangi timbulnya stres.

Hasil studi pendahuluan yang telah dilakukan oleh peneliti terhadap 20 mahasiswa yang terdiri dari angkatan 2010, 2011, 2012 dan 2013 mahasiswa Fakultas Ilmu Pendidikan Universitas Negeri Jakarta tentang persepsi wellness diperoleh data mengenai social self sebanyak 4 mahasiswa (20\%) berada pada kategori sangat rendah, 5 mahasiswa $(25 \%)$ berada pada kategori rendah, 6 mahasiswa $(30 \%)$ berada pada kategori sedang, dan 3 mahasiswa $(15 \%)$ berada pada kategori tinggi, serta 2 mahasiswa (10\%) berada pada kategori sangat tinggi. Hal ini menunjukkan bahwa ada 15 orang (75\%) mahasiswa yang kurang memiliki kemampuan sosial. Oleh karena itu, dirasa sangat penting untuk melihat profil social self of wellness pada mahasiswa Strata 1 Fakultas Ilmu Pendidikan Universitas Negeri Jakarta.

\section{Kajian Teori \\ Pengertian Wellness}

Myers, Sweeney, dan Witmer (2000: 251) mendefinisikan wellness sebagai cara hidup yang berorientasi pada kesehatan dan well-being yang optimal antara tubuh, pikiran, dan semangat terintegrasi dalam individu untuk hidup lebih utuh dalam komunitas manusia dan alam.

\section{Model Wellness}

Myers, Sweeney dan Witmer (1991: 183) mengembangkan model wellness yang disebut dengan The Wheel of Wellness. Teori ini dibangun berdasarkan psikologi individual Adler. Dalam Model tersebut dijelaskan lima tugas hidup yang digambarkan dalam roda (wheel) yang saling berhubungan dan saling berkaitan, yaitu spiritualitas, pengarahan diri, pekerjaan dan penggunaan waktu luang, persahabatan serta cinta (Myers, Sweeney dan Wit- mer, 1991: 252).

Setelah mengeluarkan model pertamanya Myers dan Sweeney (2004: 355) mengembangkan model wellness berikutnya yang disebut The Indivisible Model of Wellness (IS-Wel), model ini merupakan perbaikan dari model The Wheel of Wellness. The Indivisible Model of Wellness (IS-Wel) dikembangkan dengan menganalisis hasil dari berbagai penelitian tentang wellness, meliputi pengukuran umum tentang keseluruhan wellness dan lima dimensi urutan kedua yang membentuk keseluruhan kesejahteraan individu. Menurut Myers dan Sweeney (2004: 237) terdapat lima dimensi dalam The Indivisible Self yaitu creative self, coping self, social self, essential self, dan physical self.

\section{Pengertian Social Self}

Social self merupakan bagian dari the indivisible self. Myers dan Sweeney (2008: 485) mendefinisikan social self sebagai social support through connections with others in friendships and intimate relationships, including family ties. Menurut definisi tersebut, social self merupakan dukungan sosial melalui hubungan dengan orang lain dalam ikatan persahabatan dan hubungan personal yang lebih intens, termasuk ikatan keluarga. Social self ini terdiri dari dua aspek yang meliputi cinta dan persahabatan. Dalam social self, dukungan sosial adalah prediktor terkuat bagi kesehatan mental yang positif. Ada-nya dukungan sosial baik dari keluarga maupun lingkungan sosial, menjadi sumber kekuatan yang positif bagi kesehatan individu (Myers dan Sweeney, 2006: 11). Hal ini dapat dipahami, sebab dukungan sosial merupakan rasa nyaman, perhatian, penghargaan atau pertolongan yang dipersepsikan oleh individu yang didapat dari orang lain sebagaimana yang dikemukakan oleh Wallston (Myers dan Sweeney, 2006: 20). Dukungan sosial ini dapat berasal dari berbagai sumber, diantaranya keluarga, teman, pasangan, rekan kerja maupun organisasi sosial (Myers dan Sweeney, 2006: 60). Dukungan yang individu miliki melalui keluarga, teman-teman, dan lainnya memiliki peran besar dan berkolerasi positif dengan kesehatan fisik dan emosional serta mengurangi timbulnya stress (Myers dan Sweeney, 2005: 27). 


\section{Aspek-Aspek Social Self}

Myers dan Sweeney (2008: 486) mendefinisikan cinta sebagai "The ability to be intimate, trusting, and self disclosing with another person, having a family or family like support system characterized by shared spiritual values, the ability to solve conflict in a mutually respectful way, healthy communication styles, and mutual appreciation".

Menurut definisi di atas, cinta merupakan kemampuan untuk mengembangkan hubungan yang akrab, percaya dan terbuka terhadap orang lain, memiliki keluarga sebagai suatu sistem pendukung yang ditandai dengan berbagi nilai-nilai spiritual, kemampuan untuk menyelesaikan konflik dengan cara saling menghormati, berkomunikasi dengan cara yang sehat dan saling menghargai.

Myers dan Sweeney (2008: 486) mendefinisikan persahabatan sebagai "Social relationships that involve a connection with others individually or in community, but that do not have a marital, sexual, or familial commitment; having friends in whom one can trust and who can provide emotional, material, or informational support when needed".

Menurut definisi di atas, persahabatan merupakan hubungan sosial yang melibatkan orang lain baik secara individu maupun dalam masyarakat, tetapi tidak memiliki ikatan perkawinan atau keluarga. Selain itu, memiliki teman yang dapat dipercaya dan memberikan dukungan secara emosional, material, atau dukungan informasi bila diperlukan.

\section{Metode Penelitian}

Metode yang digunakan yaitu deskriptif dengan jenis penelitian survei. Tujuan penelitian survei yaitu untuk mengambil suatu generalisasi dari gambaran sifat keadaan yang berlangsung pada saat penelitian dilaksanakan serta memeriksa sebab-sebab dari gejala tertentu (Margono, 2007: 29). Penelitian ini dilakukan di Fakultas Ilmu Pendidikan Universitas Negeri Jakarta dan untuk waktu penelitian dilakukan sejak bulan April sampai dengan November 2014. Populasi dalam penelitian ini adalah seluruh mahasiswa Strata 1 Fakultas Ilmu Pendidikan Universitas Negeri Jakarta angkatan 2011 sampai dengan angkatan 2014 yang berjumlah 3.291 maha- siswa. Dalam menentukan jumlah sampel yang akan diambil dari populasi, peneliti menggunakan tabel bernama tabel Nomogram Herry King (Sugiyono, 2008 : 127).

Populasi penelitian berjumlah 3.291 mahasiswa, pada tabel tersebut dengan taraf kesalahan 5\% menunjukkan jumlah sampel sebanyak 317 mahasiswa. Penentuan sampel pada penelitian ini menggunakan teknik proportionate stratified random sampling, yaitu sampel yang ditarik dengan memisahkan elemen-elemen populasi dalam kelompok-kelompok yang tidak overlapping yang disebut strata, dan kemudian memilih sebuah sampel secara random dari setiap stratum (Nasir, 2009: 291). Teknik pengumpulan data yang dipakai menggunakan kuesioner social self dengan menggunakan skala likert yang dibuat dengan lima alternatif jawaban, yaitu selalu (SL), sering (SR), kadang-kadang (KK), jarang (JR) dan tidak pernah (TP). Pembobotan skor pada masing-masing alternatif jawaban untuk item positif skor sebagai berikut: 5, 4, 3, 2, 1 sedangkan untuk item negatif sebaliknya. Sebelum instrumen digunakan, dilakukan uji coba terlebih dahulu kepada 30 mahasiswa Fakultas Ilmu Pendidikan untuk mengukur tingkat validitas dan reliabilitas instrumen. Hasil pengujian validitas butir sebanyak 31 item yang valid dan 13 item yang tidak valid. Hasil perhitungan reliabilitas dengan rumus Alpha Cronbach diperoleh koefisien reliabilitas sebesar 0,886. Teknik analisis data yang digunakan dalam penelitian ini adalah statistik deskriptif. Statistik deskriptif adalah statistik yang digunakan untuk menganalisa data dengan cara mendeskripsikan atau menggambarkan data yang telah terkumpul tanpa bermaksud membuat kesimpulan yang berlaku untuk umum atau generalisasi (Sugiyono, 2008: 207).

\section{Hasil dan Pembahasan Hasil Penelitian}

Secara keseluruhan profil social self of wellness mahasiswa strata 1 Fakultas Ilmu Pendidikan Universitas Negeri Jakarta dapat divisualisasikan dalam bentuk tabel kategorisasi sebagai berikut: 
Tabel 1

Kategori Social Self Of Wellness Mahasiswa Strata 1 Fakultas IImu Pendidikan Universitas Negeri Jakarta (Data Keseluruhan)

\begin{tabular}{|c|c|c|c|}
\hline Kategorisasi & Rentang Skor & Frekuensi & Persentase \\
\hline Rendah & $\leq 77$ & 0 & 0 \\
\hline Sedang & $77-121$ & 146 & 46,1 \\
\hline Tinggi & $\geq 121$ & 171 & 53,9 \\
\hline \multicolumn{2}{|c|}{ Jumlah } & 317 & 100,0 \\
\hline
\end{tabular}

Berdasarkan tabel ini diketahui bahwa sebagian besar profil social self of wellness mahasiswa strata 1 Fakultas Ilmu Pendidikan Universitas Negeri Jakarta berada pada kategori tinggi sebesar 53,9\% (171 mahasiswa), pada kategori sedang sebesar 46,1\% (146 mahasiswa), sedangkan untuk kategori rendah tidak ada. Hasil tersebut menunjukkan bahwa sebagian besar mahasiswa strata 1 Fakultas Ilmu Pendidikan Universitas Negeri Jakarta memiliki kemampuan social self yang baik dan berada pada kondisi yang sehat. Artinya mahasiswa strata 1 Fakultas Ilmu Pendidikan Universitas Negeri Jakarta memiliki kemampuan untuk mengembangkan hubungan yang akrab dengan orang lain, memiliki kemampuan untuk dapat mempercayai orang lain, terbuka terhadap orang lain, memiliki keluarga se-bagai suatu sistem pendukung yang ditandai dengan berbagi nilai-nilai spiritual, mampu menyelesaikan konflik dengan cara saling menghormati, mampu berkomunikasi dengan cara yang sehat, mampu menghargai orang lain, mampu berhubungan de-ngan orang lain baik secara individu dalam masyarakat (di luar keluarga atau memiliki hubungan pernikahan), memiliki teman yang dapat dipercaya, memiliki teman yang dapat memberi dukungan secara emosional serta memiliki teman yang dapat memberikan dukungan secara materil atau informasi ketika dibutuhkan.

Berdasarkan jurusan diperoleh hasil bahwa pada Jurusan Bimbingan dan Konseling perolehan hasil antara kategori tinggi dan sedang sama yaitu sebesar 50\% (15 mahasiswa), sedangkan untuk kategori rendah tidak ada. Hal ini menunjukkan bahwa sebagian mahasiswa Jurusan Bimbingan dan Konseling memiliki kemampuan social self yang baik, serta sebagian mahasiswa lainnya cukup memiliki kemampuan social self, akan tetapi masih perlu mengembangkan kemampuan pada indikator dapat mempercayai orang lain dan terbuka terhadap orang lain.
Pada Jurusan Manajemen Pendidikan perolehan hasil sebesar 41,4\% (12 mahasiswa) pada kategori tinggi, 58,6\% (17 mahasiswa) pada kategori sedang, dan tidak ada pada kategori rendah. Hal ini menunjukkan bahwa sebagian besar mahasiswa Jurusan Manajemen Pendidikan cukup memiliki kemampuan social self, akan tetapi mahasiswa Jurusan Manajemen Pendidikan perlu mengembangkan kemampuan pada indikator berhubungan dengan orang lain baik secara individu dalam masyarakat (diluar keluarga atau memiliki hubungan pernikahan), kemampuan untuk dapat mempercayai orang lain serta mampu terbuka terhadap orang lain. Kemudian, pada Jurusan Psikologi perolehan hasil pada kategori tinggi sebesar 48,1\% (26 mahasiswa), pada kategori sedang sebesar 51,9\% (28 mahasiswa), sedangkan untuk kategori rendah tidak ada. Hal ini menunjukkan bahwa sebagian besar mahasiswa Jurusan Psikologi cukup memiliki kemampuan social self, akan tetapi mahasiswa Jurusan Psikologi perlu mengembangkan kemampuan pada indikator dapat mempercayai orang lain, terbuka terhadap orang lain serta memiliki teman yang dapat dipercaya.

Pada Jurusan Pendidikan Guru Pendidikan Anak Usia Dini sebagian besar mahasiswa berada pada kategori tinggi yaitu 69,4\% (25 mahasiswa), pada kategori sedang sebesar 30,6\% (11 mahasiswa), sedangkan untuk kategori rendah tidak ada. Hal ini menunjukkan bahwa sebagian besar mahasiswa Jurusan Pendidikan Guru Pendidikan Anak Usia Dini memiliki kemampuan social self yang baik. Selain itu, pada Jurusan Pendidikan Guru Sekolah Dasar sebagian besar mahasiswa berada pada kategori tinggi yaitu 51,3\% (41 mahasiswa), pada kategori sedang sebesar 48,8\% (39 mahasiswa), sedangkan untuk kategori rendah tidak ada. Hal ini juga menunjukkan bahwa sebagian besar mahasiswa Jurusan Pendidikan Guru Sekolah Dasar memiliki kemampuan social self yang baik.

Selanjutnya, pada Jurusan Pendidikan Luar Biasa sebagian besar mahasiswa berada pada kategori tinggi sebesar 53,3\% (16 mahasiswa), pada kategori sedang sebesar 46,7\% (14 mahasiswa), sedangkan untuk kategori rendah tidak ada. Hal ini menunjukkan bahwa sebagian besar mahasiswa Jurusan Pendidikan Luar Biasa memiliki kemampuan social self yang baik. Selain itu, pada Jurusan Pendidikan Lu- 
ar Sekolah sebagian besar mahasiswa berada pada kategori tinggi sebesar 62,1\% (18 mahasiswa), pada kategori sedang sebesar 37,9\% (11 mahasiswa), sedangkan untuk kategori rendah tidak ada. Hal ini juga menunjukkan bahwa sebagian besar mahasiswa Jurusan Pendidikan Luar Sekolah memiliki kemampuan social self yang baik. Selanjutnya, pada Jurusan Kurikulum dan Teknologi Pendidikan sebagian besar mahasiswa berada pada kategori tinggi sebesar 55,2\% (16 mahasiswa), pada kategori sedang sebesar 44,8\% (13 mahasiswa), sedangkan untuk kategori rendah tidak ada. Hal ini juga menunjukkan bahwa sebagian besar mahasiswa Jurusan Kurikulum dan Teknologi Pendidikan memiliki kemampuan social self yang baik.

Berdasarkan angkatan diperoleh hasil bahwa pada mahasiswa angkatan 2011 sebagian besar berada pada kategori tinggi yaitu 59,1\% (52 mahasiswa), pada kategori sedang sebesar 40,9\% (36 mahasiswa), sedangkan untuk kategori rendah tidak ada. Selain itu, pada angkatan 2012 sebagian besar berada pada kategori tinggi yaitu 51,1\% (47 mahasiswa), pada kategori sedang sebesar $48,9 \%$ (45 mahasiswa), sedangkan untuk kategori rendah tidak ada. Akan tetapi, pada angkatan 2013 perolehan hasil pada kategori tinggi sebesar 46,5\% (33 mahasiswa), pada kategori sedang sebesar 53,5\% (38 mahasiswa), sedangkan untuk kategori rendah tidak ada. Hasil tersebut menunjukkan bahwa mahasiswa angkatan 2013 sebagian besar berada pada kategori sedang. Selanjutnya, pada angkatan 2014 sebagian besar mahasiswa berada pada kategori tinggi yaitu 59,1\% (39 mahasiswa), pada kategori sedang sebesar 40,9\% (27 mahasiswa), sedangkan untuk kategori rendah tidak ada.

Hasil tersebut menunjukkan bahwa sebagian besar mahasiswa strata 1 Fakultas Ilmu Pendidikan Universitas Negeri Jakarta dilihat berdasarkan angkatan berada pada kategori tinggi, hanya saja pada angkatan 2013 sebagian besar mahasiswa berada pada kategori sedang dengan persentase sebesar $53,5 \%$. Menurut NCES hal ini dikarena pada tahun ke dua di perguruan tinggi ada peningkatan proporsi perkuliahan yang berorientasi kejuruan atau mata kuliah keahlian, sehingga mahasiswa mulai merasakan adanya beban mata kuliah tertentu yang khusus, jadwal perkuliahan mulai padat dan tugas perku- liahan semakin banyak.

Berdasarkan jenis kelamin, pada laki-laki menunjukkan hasil sebesar 12\% (9 mahasiswa) pada kategori tinggi, 88\% (66 mahasiswa) pada kategori sedang, sedangkan pada kategori rendah tidak ada. Pada perempuan diperoleh hasil sebesar 66,9\% (162 mahasiswa) pada kategori tinggi, 33,1\% (80 mahasiswa) pada kategori sedang, dan tidak ada pada ka-tegori rendah. Hasil tersebut menunjukkan bahwa sebagian besar mahasiswa laki-laki berada pada kategori sedang dengan persentase sebesar $88 \%$, sedangkan mahasiswa perempuan sebagian besar berada pada kategori tinggi dengan persentase sebesar $66,9 \%$. Hal tersebut menunjukan bahwa perempuan memiliki kemampuan sosial yang baik dibandingkan dengan laki-laki. Hal ini senada dengan pendapat Ryff yang menyatakan bahwa antara lakilaki dan perempuan menunjukkan perbedaan yang signifikan mengenai hubungan positif dengan orang lain. Hal tersebut dikarenakan sejak kecil, stereotype gender telah tertanam dalam diri anak laki-laki yang digambarkan sebagai sosok yang agresif dan mandiri. Sementara itu, perempuan digambarkan sebagi sosok yang pasif dan tergantung, serta sensitif terhadap perasaan orang lain.

\section{Simpulan dan Saran}

Berdasarkan hasil penelitian yang telah dilakukan oleh peneliti, mengenai profil social self of wellness mahasiswa strata 1 Fakultas Ilmu Pendidikan Universitas Negeri Jakarta maka dapat disimpulkan bahwa kemampuan social self mahasiswa berada pada kategori tinggi sebesar 53,9\% (171 mahasiswa). Hal tersebut menunjukkan bahwa sebagian besar mahasiswa strata 1 Fakultas Ilmu Pendidikan Universitas Negeri Jakarta memiliki kemampuan social self yang baik.

Saran berdasarkan hasil penelitian adalah:

1. Bagi Unit Layanan Bimbingan dan Konseling Universitas Negeri Jakarta, penelitian ini memberikan informasi mengenai profil social self of wellness mahasiswa strata 1 Fakultas Ilmu Pendidikan Universitas Negeri Jakarta, dengan mendapatkan data hasil penelitian ini, Unit Layanan Bimbingan dan Konseling dapat membuat perencanaan layanan bagi mahasiswa strata 1 
Fakultas Ilmu Pendidikan Universitas Negeri Jakarta.

2. Bagi jurusan di Fakultas Ilmu Pendidikan Universitas Negeri Jakarta, data hasil penelitian ini dapat dijadikan informasi untuk menerapkan strategi pembelajaran yang mendorong pengembangan kemampuan social self mahasiswa.

3. Bagi Jurusan Bimbingan dan Konseling, agar mahasiswa memiliki kehidupan pribadi dan kompetensi profesional yang stabil maka mahasiswa diharapkan mampu mencapai kesejahteraan mental, emosional dan sosial. Oleh karena itu, perlu adanya program pelatihan seperti pelatihan yang berkaitan dengan problem solving, stress ma-nagement, anger management, dan self control dalam rangka pengembangan pribadi konselor agar calon guru Bimbingan dan Konseling lebih kompeten dan siap menghadapi keadaan di lapangan nanti.

4. Bagi peneliti selanjutnya yang ingin melakukan penelitian mengenai social self dapat melakukan penyempurnaan terhadap hasil penelitian ini, antara lain dapat melakukan penelitian secara kualitatif atau kuantitatif mengenai faktor-faktor yang mempengaruhi social self mahasiswa.

\section{Daftar Pustaka}

Hattie A John, J.E. Myers, \& Thomas J. A Sweeney. (2004). A Factor Structure of Wellness: Theory, Assessment, Analysis, and Practice. Journal Of Counseling \& Development, Volume 82

Margono. (2007). Metodologi Penelitian Pendidikan. Jakarta: Rineka Cipta

Myers, E. J \& T. J Sweeney. (2005). Counseling for Wellness. Alexandria: American Counseling Association

----(2008). Wellness Counseling: The Evidence Base for Practice. Journal of Counseling \& Development. Volume 86

----(2004). The Indivisible Self: An Evidence Based Model of Wellness. Journal of Individual Psychology

----(2006). The Five Factor Wellness \& Habit Change Workbook. Mind Garden inc

Myers, E.J. (1991). Wellness as the paradigm for counseling and development: The Possible future. Counselor Education and supervision. Volume. 30. No. 3

Myers, E.J, Thomas J. Sweeney and J. Melvin Witmer. (2000). The Wheel of Wellness Counseling for Wellness: A Holistic Model for Treatment Planning. Journal of Counseling and Development. Volume. 78. No.1

Nasir, Moh.( 2008). Metode Penelitian. Jakarta :Ghalia Indonesia

Sugiyono. (2008). Metode Penelitian Pendidikan : Pendekatan Kualitatif, Kuantitatif dan R \& D. Bandung: Alfabeta 